\title{
DECOUPLED HOMOGENIZATION OF HYPERELASTIC COMPOSITE WITH CARBON BLACK INCLUSION
}

\author{
Martyna Poręba-Sebastjan, Waclaw KuŚ* \\ Department for Computational Mechanics and Engineering, \\ Silesian University of Technology, Konarskiego 18A, 44-100 Gliwice, Poland \\ *Corresponding author: waclaw.kus@polsl.pl
}

\begin{abstract}
The goal of the paper is to present the application of decoupled homogenization method to the modeling of hyperelastic composite with inclusions. The method presented in the paper is illustrated by numerical analysis of a trunk door seal. The decoupled homogenization method was used to find macroscale properties of hyperelastic material. The method allows for the determination of the equivalent properties of a composite material based on its structure and the results of numerical experiments. Unlike the coupled method, the results are not transferred in every iteration between scales during computations which leads to lower calculation costs. The analyzed micro model consisted of a hyperelastic matrix and stiff inclusions in the form of spheres of carbon black material. The decoupled procedure uses evolutionary algorithm to obtain macro model material properties. The finite element method is used during analyses of micro scale models.
\end{abstract}

Key words: Decoupled homogenization, Evolutionary algorithm, Composite, Hyperelastic material

\section{INTRODUCTION}

Nowadays, reducing the time of numerical calculations without changing the quality of calculations is one of the top prorities. For this purpose, among others, homogenization is being used (Madej et al., 2008; Fish, 2013; Rauch et al., 2015), which allows one to find equivalent material properties for complex structures and replace composite with homogeneous structure. This has the effect of shortening the time of creating a numerical model and a significant acceleration of numerical analysis with a smaller number of finite elements. In the paper, the equivalent, macro scale, material properties of hyperelastic matrix with inclusions of carbon black using evolutionary algorithms are determined. The presented method is general and can be used for various types of composites with inclusions. The resulting equivalent material properties can be used in macro structure analysis allowing significant simulation time reduction.
Section 2 of the paper describes hyperelastic material models and the carbon black inclusion parameters. The Representative Volume Element (RVE) creation and decoupled homogenization schema is presented. The Evolutionary Algorithm (EA) used during decoupled procedure and the optimization problem formulation are shown. Section 3 presents the results of a numerical modeling of a trunk seal using methods described in section 2 .

\section{MATERIALS AND METHODS}

\subsection{Hyperelastic materials}

Hyperelastic materials are described in the works by Fung (1993), Rackl (2015), Prevost et al. (2011). These materials can undergo large elastic deformations while retaining their original properties. During deformation, models with hyperelastic properties behave in a non-linear manner and deformations are not directly proportional to the given 
load. These materials can only be subjected to isochoric deformations, which do not affect the volume change. Hyperelastic materials are based on the definition of the strain density energy function $\mathrm{W}$. The stress components are shown in the equation:

$$
S_{i j}=\frac{\partial\left(\rho_{0} W\right)}{\partial E_{i j}}
$$

where: $\rho_{0}$ - the density in the zero-stress state, $E_{i j}$ the strain tensor component, $S_{i j}$ - the stress tensor component.

The strain energy can also be represented by the Lagrangian stresses $T_{i j}$, as shown in the following equation:

$$
T_{i j}=\frac{\partial\left(\rho_{0} W\right)}{\partial\left(\frac{\partial x_{i}}{\partial a_{j}}\right)}
$$

where: $\partial x_{i} / \partial a_{j}$ - the deformation gradient tensor, $x_{i}$ the coordinates for the deformed state of the body in cartesian coordinates, $a_{j}$ - coordinates in a state of zero stress of the body.

The relationship between the Cauchy $\sigma_{i j}$, Lagrange $T_{i j}$ and Kirchhoff $S_{i j}$ stresses are presented below:

$$
\begin{aligned}
& T_{i j}=S_{i p} \frac{\partial x_{j}}{\partial a_{p}} \quad S_{i j}=\frac{\partial a_{i}}{\partial x_{\alpha}} T_{j \alpha} \\
& \sigma_{i j}=\frac{\rho}{\rho_{0}} \frac{\partial x_{i}}{\partial a_{p}} T_{p i}=\frac{\rho}{\rho_{0}} \frac{\partial x_{i} \partial x_{j}}{\partial a_{\infty} \partial a_{\beta}} S_{\beta \alpha} \\
& T_{i j}=\frac{\rho_{0}}{\rho} \frac{\partial a_{j}}{\partial x_{m}} \sigma_{m i} \quad S_{i j}=\frac{\rho_{0}}{\rho} \frac{\partial a_{i}}{\partial x_{\alpha}} \frac{\partial a_{j}}{\partial x_{m}} \sigma_{m \alpha}
\end{aligned}
$$

The constitutive equation for hyperelastic models is given by equation (6), which depends on the invariants of the Cauchy-Green deformation tensor:

$$
W=W\left(I_{1}, I_{2}, I_{3}\right)=W\left(I_{1}, I_{2}, J\right)
$$

where: $W-$ strain energy function, $I_{i}$ - invariant of deformation tensor, $J$ - isochoric deformation.

The expansion using invariant equations is shown below:

$$
\begin{aligned}
& I_{1}=\lambda_{1}^{2}+\lambda_{2}^{2}+\lambda_{3}^{2} \\
& I_{2}=\lambda_{1}^{2} \lambda_{2}^{2}+\lambda_{2}^{2} \lambda_{3}^{2}+\lambda_{3}^{2} \lambda_{1}^{2} \\
& I_{3}=\lambda_{1}^{2} \lambda_{2}^{2} \lambda_{3}^{2}=J^{2}
\end{aligned}
$$

where: $\lambda_{i}^{2}$ - principal stretches.
Strain energy of incompressible material is a function of two invariants of the deformation tensor and takes the form of the equation:

$S_{i j}=\frac{\partial\left(\rho_{0} W\right)}{\partial E_{i j}}$

Typical hyperelastic materials models can be grouped into three categories:

- Nearly-/fully-incompressible based on strain invariants:

a) Mooney-Rivlin (1st and 2nd strain invariants),

b) Yoeh (1st strain invariant),

c) Neo-Hookean (1st strain invariant).

- Nearly-/fully-incompressible based on 1st strain invariants:

a) Arruda-Boyce (1st strain invariant),

b) Gent (1st strain invariant).

- Incompressible based on principal stretches:

a) Ogden.

Depending on the choice of the type of MooneyRivlin material model, they are characterized by the possibility of using them for specific strain ranges. In the case of a 2-term model, its range of applicability is 90 to $100 \%$, but it does not properly describe the compression effect. For 5- and 9-term models, they are suitable for deformations above $100 \%$ up to 200\%. The 9-terms Mooney-Rivlin material model, which strain energy function is represented by the following equation is used in the paper:

$W=\sum_{i+j=1}^{3} c_{i j}\left(I_{1}-3\right)^{i}\left(I_{2}-3\right)^{j}+\frac{1}{d}\left(J_{e l}-1\right)^{2}$

where: $d, c_{i, j}$ - material constants, $J_{e l}$ - elastic volume coefficient.

Initial bulk modulus $\kappa_{0}$ is determined by the formula (10):

$\kappa_{0}=\frac{1}{d}$

\subsection{Carbon black as the inclusions material}

Carbon black is described in the works by Kyungwhan et al. (2018), Lopez Jimenez \& Pellegrino (2012) and $\mathrm{Xu}$ et al. (2012). The material is pure elemental carbon in the form of colloidal particles. It is usually produced in the form of furnace carbon black and thermal carbon black. The first type of production process uses heavy aromatic oils that are pyrolysis at controlled pressure and temperature. Natural gas is used to generate thermal carbon black, which is decomposed into technical carbon 
black and in hydrogen in a hot furnace. Both processes have limited access to air during production. The final product of these two production processes is carbon black in the form of fine granules or powder.

There are different types of carbon black, for example:

a) N 550 - characterized by inclusions with a small surface area and low abrasion resistance. Provides production of extruded profiles, hoses, belts, brake diaphragms, and plastic piping with the greatest accuracy (web page Industrial Rubber Carbon Blacks).

b) N 762 - characterized by low reinforcing and high loading capacity. Used for the production of hoses, molded goods (web page Industrial Rubber Carbon Blacks). c) N 990 - provides improvement of key dynamic properties while reducing the cost of quality of nitrile compounds (Thompson, 2010).

The carbon black sample structures are shown in figure 1 .

Carbon black is mainly used for the production of tires and other rubber products and as a pigment for paints and polymer filler materials. The carbon black structure is characterized by the fact that it is distributed in random way and different sizes of inclusions can be present in composite. In order to determine the homogenized properties of the composite with carbon black inclusions, the RVE model was build. The RVE is constructed on the base of known distribution of sizes of inclusions and known spherical shape. To build the RVE histograms taking into account the percentage of the volume of inclusions were used (figure 2). a)

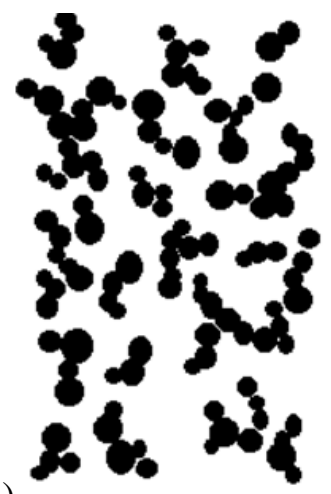

b)

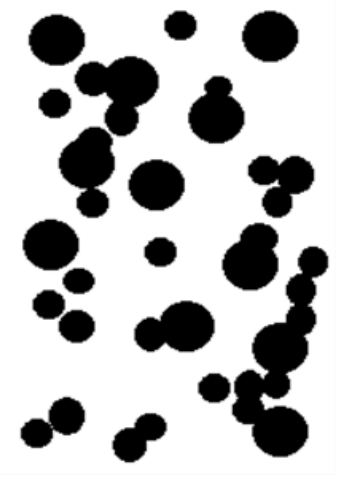

c)

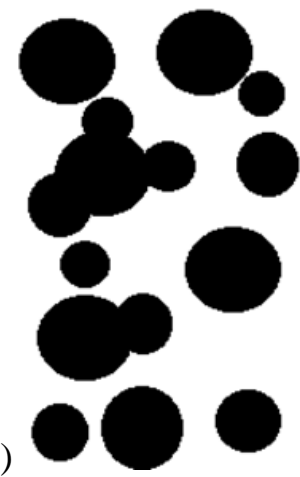

Fig. 1. Structure Classification of example carbon black: a) high structure N550; b) moderate structure N762; c) low structure N990 (Thompson, 2010).

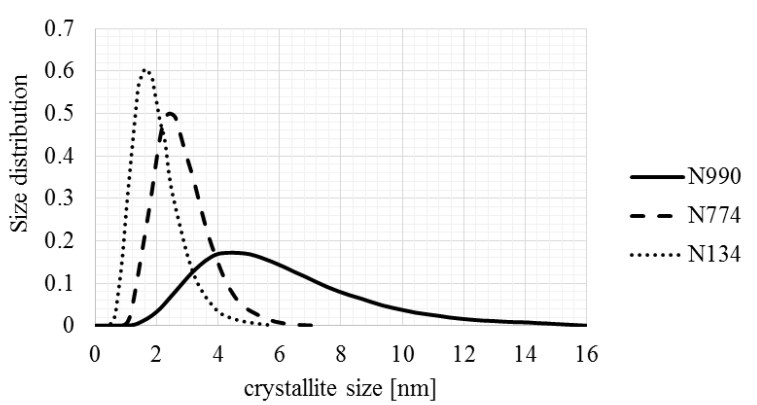

a)

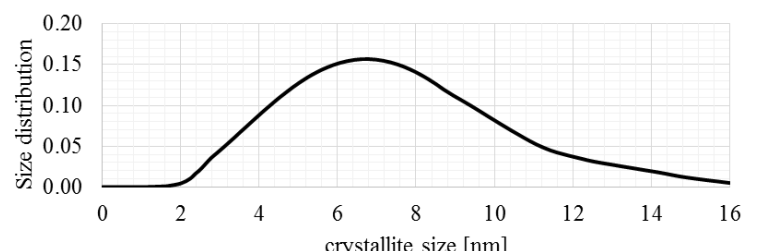

b)

crystallite size $[\mathrm{nm}]$

Fig. 2. Crystallite size distribution for a) N990, N774 and N134 (Ungar et al., 2002), b) size distribution used in the paper.

\subsection{Evolutionary algoritm (EA)}

The optimization problems with multimodal objective functions were solved using evolutionary algorithms (Michalewicz (1996); Burczyński et al. (2020)), which implement mechanisms similar to those found in natural evolution of species. Individuals compete with each other, cross each other, mutate until they get the best fit for optimization criteria. The individuals carry information about design variables in chromosomes containing genes. The one chromosome individuals are considered in the paper. The genes can directly be used as a design variable due to use of floating-point representation. The EA iterative algorithm flowchart is as follows:

a) the initial population is created,

b) the fitness function is evaluated for each individual(chromosome),

c) the condition of detention is checked,

d) individuals(chromosomes) are selected, 
e) genetic operators are used,

f) a new population is created,

g) go to b) if the stop condition is not fulfilled.

The selection consists of selecting the chromosomes that will be used to create the next generation. Selection alone does not introduce any new individual into the population. In the article, rank selection was used, which consists of arranging the individuals according to the value of adaptation and selection according to the order. In the evolutionary algorithm, crossover operation and mutations are used as the basic evolutionary operators, the first of which always occurs and the second is not necessarily. The crossover operator can be divided into simple and arithmetic. The first of these is the exchange of cutoff parts of genetic material and the emergence of two new chromosomes. Arithmetic crossing, on the other hand, consists in creating an individual consisting of a linear combination of gene values from parental individuals. There are many mutation operators distinguished: uniform, with Gaussian distribution, or boundary. In this article the first two were used, therefore the differences between them will be briefly presented. The mutation with the Gaussian distribution can be distinguished from the even mutation by the fact that it is characterized by a random gene selection in the chromosome using the Gaussian distribution and not with a uniform distribution. The optimization multipopulation, version of evolutionary algorithm, also called distributed evolutionary algorithms (Burczyński et. al, 2020) is used in the paper. The population of individuals is divided into subpopulations. The subpopulations evolve in almost independent way, only from time to time a migration of certain individuals occurs, causing the exchanging of individuals between subpopulations.

\subsection{Decoupled homogenization scheme}

The decoupled homogenization method is used to determine the surrogate properties of the composite made from hyperelastic material with stiff elastic inclusions. A detailed description of the decoupled homogenization method can be found in the work by Terada et al. (2013). To identify homogenized material parameters for macroscale, numerical material tests (NMT) in microscale are performed. The number of test and boundary conditions should be determined in such a way that the composite properties are best reflected on a macro scale. The models in micro scale in the paper are numerically tested for boundary conditions showed in figure 3 . a)

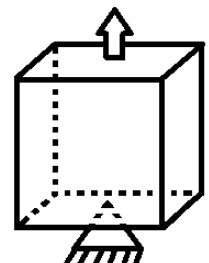

f)

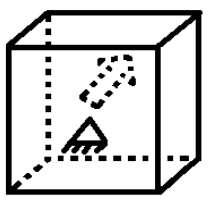

k)

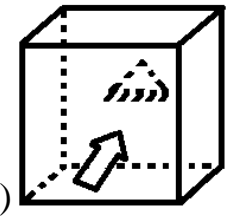

p)

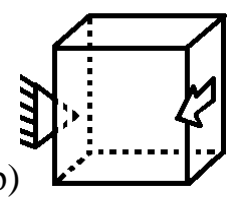

b)

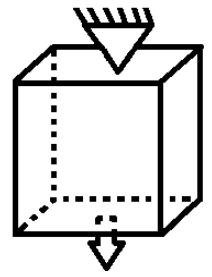

g)

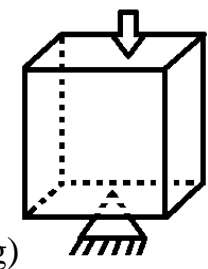

1)

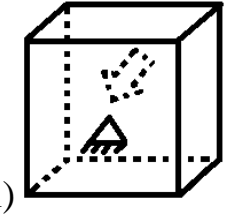

r)

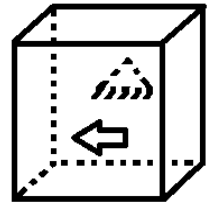

c)

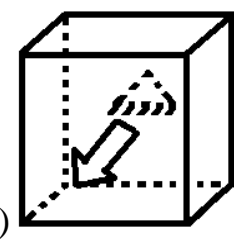

h)

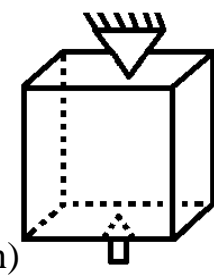

m)

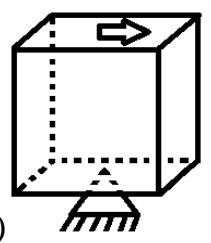

s)

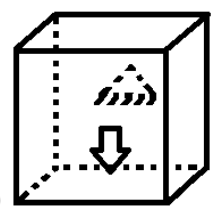

d)

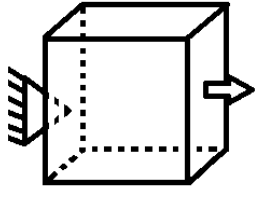

i)

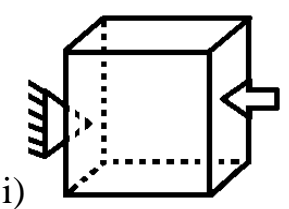

n)

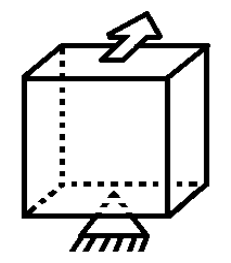

Fig. 3. The numerical material tests in microscale: a) extension $z+; b)$ extension $z-; c$ ) extension $y$-; d) extension $x+; e)$ extension $x$-; $f$ extension $y+;$ g) compression $z-;$ h) compression $z+; i)$ compression $x-; j$ ) compression $x+; k$ ) compression $y+$; l) compression $y$-; m) shear $x+; n$ ) shear $y+;$ ) shear $z+;$ ) shear $y$-; r) shear $x-;$ ) shear $z-;$ ) coordinate system.

Z

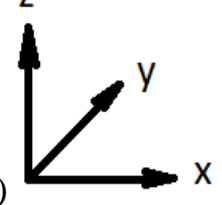

o)
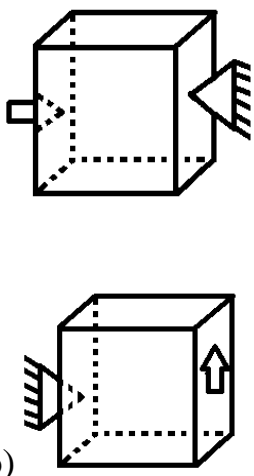

e)

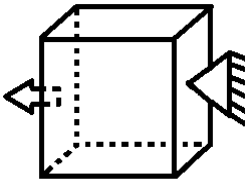

j) 
The decoupled method allows computations to be performed in each scale without transferring strains and stresses fields between models in each step. The constitutive equation for the macroscale is discovered on the basis of the numerical tests at the microscale composite model. The result of numerical tests in microscale like stress-strain or forcedisplacements relations are used to determine equivalent, homogenized, hyperelastic material properties in macro scale. The problem of obtaining material properties is formulated as a optimization problem and must be solved using global optimization method due to multimodal objective function. The evolutionary algorithms are used in the paper to solve the optimization problem. The hyperelastic material properties for homogenized model are coded into genes of a chromosome. The micromodel was analysed by prescribing displacements and measuring reaction forces. The value of the objective function is the sum of relative errors for each load case $c$ and applied displacements:

$f(\mathbf{c h})=\sum_{c=1}^{m} \sum_{i=1}^{n} \frac{\left|x(\mathbf{c h})_{c i}-x_{0 c i}\right|}{\left|x_{0 c i}\right|} * 100 \%$

where: $x_{0 c i}$ - means reaction value from the micromodel, $x(\mathbf{c h})_{c i}$ - reaction value from the homogenized model for material parameters described by chromosome ch genes, for displacement step $i$ and load case $c$.

The box constrains on the gene's values are used. The closer the fitness function is to zero, the better matched are the micro and homogenized model results. The material properties of the composite in micromodel can be different than in homogenized model.

\section{NUMERICAL EXAMPLE}

The trunk door seal made of a composite material is analyses as a numerical example. The matrix was made of hyperelastic material, while the elastic inclusions were in the form of carbon black. The decoupled method presented in previous section was used.

The carbon black model showed in figure $2 b$ is used in the numerical example. The distribution of sizes of the inclusions used in the micro model is shown in table 1.
Table 1. The size distribution of carbon black.

\begin{tabular}{|c|c|}
\hline Diameter, nm & PCS \\
\hline 2 & $4 \mathrm{pcs}$ \\
\hline 4 & $16 \mathrm{pcs}$ \\
\hline 6 & $10 \mathrm{pcs}$ \\
\hline 8 & $7 \mathrm{pcs}$ \\
\hline 12 & $1 \mathrm{pc}$ \\
\hline
\end{tabular}

The volumes of all inclusions were calculated and totaled $4465 \mathrm{~nm}^{3}$. This represents $10 \%$ of the total volume. The $35 \times 35 \times 35 \mathrm{~nm}$ cube was analyzed as a micro model. The carbon black numerical model ultimately consisted of the inclusions, shown in figure 4 .

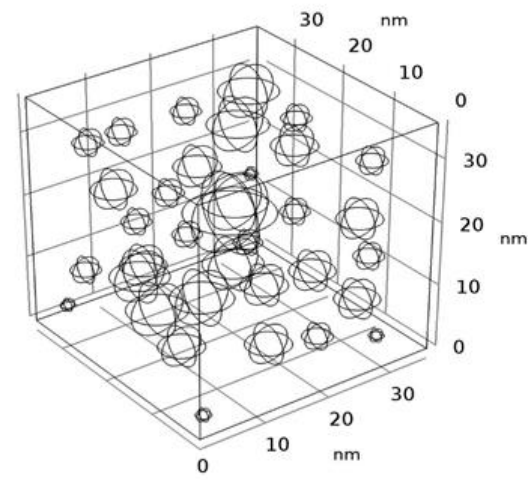

Fig. 4. The geometry of the hyperelastic matrix with the carbon black inclusions.

The carbon black model was discretized using finite elements, as shown in figure 5. Detailed information about finite elements is given in table 2 .

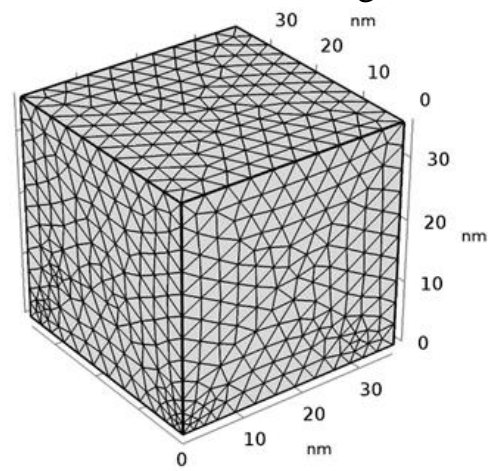

a)

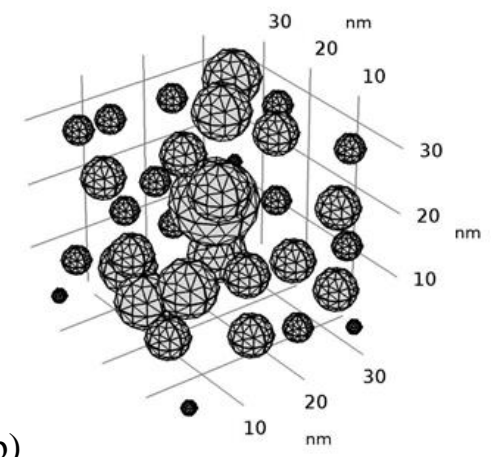

b)

Fig. 5. A FEM model: a) micromodel; b) CB inclusions. 
Table 2. Data used for material description in numerical modeling.

\begin{tabular}{|c|c|c|c|}
\hline $\begin{array}{c}\text { Mesh } \\
\text { vertices }\end{array}$ & $\begin{array}{c}\text { Tetrahedral } \\
\text { elements }\end{array}$ & $\begin{array}{c}\text { Triangular } \\
\text { elements }\end{array}$ & $\begin{array}{c}\text { Edge } \\
\text { elements }\end{array}$ \\
\hline 8578 & 48198 & 6260 & 1407 \\
\hline $\begin{array}{c}\text { Vertex } \\
\text { elements }\end{array}$ & $\begin{array}{c}\text { Number of } \\
\text { elements }\end{array}$ & $\begin{array}{c}\text { Shape func- } \\
\text { tion }\end{array}$ & \\
\hline 218 & 48198 & Quadratic & \\
\hline
\end{tabular}

The Mooney-Rivlin 9 parameter material was used at matrix micro model and homogenized model. The value of the fitness function of the parent algorithm is specified in equation (5). The maximum number of executions of an evolutionary algorithm was 50. Parameters of the algorithm were as follows: probability of even mutation 0.1 , probability of Gaussian mutation 0.8 , probability of simple crossing 0.8 , probability of arithmetic crossing 0.2 , number of individuals in subpopulations 16 , number of subpopulations 2. The matrix hyperelastic MooneyRivlin 9-parameters material model are shown in table 3. Elastic material properties for the carbon black model are presented in table 4 .

Table 3. Material parameters of M-R 9-parameters for matrix in micro model [MPa] (Gorash et al., 2015), EO - initial bulk modulus.

\begin{tabular}{|c|c|c|c|c|}
\hline $\mathrm{C} 10$ & $\mathrm{C} 01$ & $\mathrm{C} 20$ & $\mathrm{C} 02$ & $\mathrm{C} 11$ \\
\hline 0.172 & $9.52 \times 10^{-3}$ & $-1.95 \times 10^{-3}$ & $-1.24 \times 10^{-4}$ & $3.44 \times 10^{-4}$ \\
\hline $\mathrm{C} 30$ & $\mathrm{C} 03$ & $\mathrm{C} 21$ & $\mathrm{C} 12$ & $E_{0}, \mathrm{~Pa}$ \\
\hline $4.66 \times 10^{-5}$ & $-1.28 \times 10^{-7}$ & $5.29 \times 10^{-8}$ & $3.56 \times 10^{-6}$ & $3.60 \times 10^{6}$ \\
\hline
\end{tabular}

Table 4. Material parameters of carbon black (Xu et al., 2012).

\begin{tabular}{|c|c|c|}
\hline $\begin{array}{c}\text { Young's modulus, } \\
\mathrm{MPa}\end{array}$ & Poisson's ratio & Density, $\mathrm{g} / \mathrm{cm}^{3}$ \\
\hline 2500 & 0.3 & 1.8 \\
\hline
\end{tabular}

The micromodel was computed for load cases presented in figure 3. An exemplary distribution of displacements for stretching in the " $z$ " direction is shown in figure 6 . The maximum displacement value for the case of stretching along the $Z$ axis was 35 $\mathrm{nm}$. The numerical homogenized model of the cube contains low number of elements and is shown in figure 7. Detailed information about model with homogenized material mesh can be found in table 5 .

Table 5. Detailed information on finite elements for homogenized cube.

\begin{tabular}{|c|c|c|c|}
\hline $\begin{array}{c}\text { Mesh verti- } \\
\text { ces }\end{array}$ & $\begin{array}{c}\text { Hexahedral } \\
\text { elements }\end{array}$ & $\begin{array}{c}\text { Quadrilat- } \\
\text { eral ele- } \\
\text { ments }\end{array}$ & $\begin{array}{c}\text { Edge ele- } \\
\text { ments }\end{array}$ \\
\hline 343 & 216 & 216 & 72 \\
\hline $\begin{array}{c}\text { Vertex } \\
\text { elements }\end{array}$ & $\begin{array}{c}\text { Number of } \\
\text { elements }\end{array}$ & $\begin{array}{c}\text { Shape func- } \\
\text { tion }\end{array}$ & \\
\hline 8 & 216 & Quadratic & \\
\hline
\end{tabular}

a)
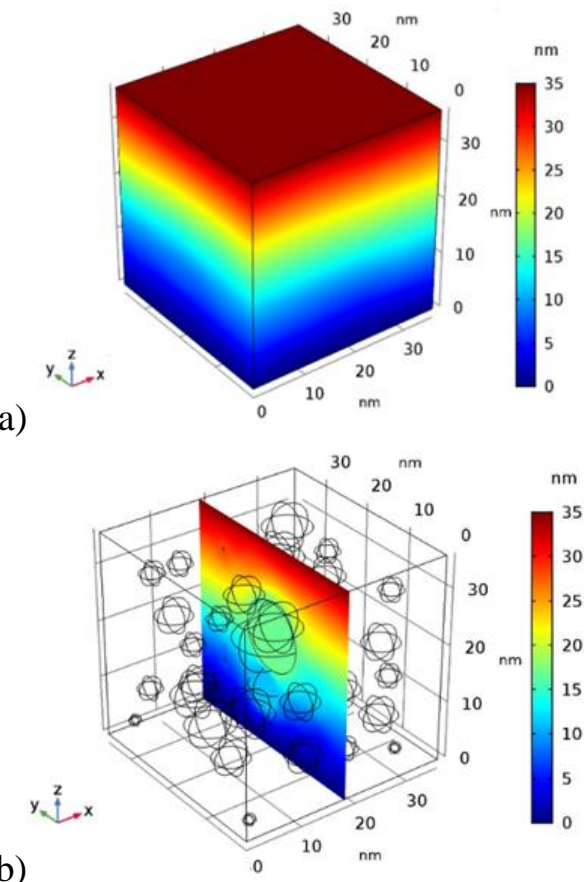

Fig. 6. Exemplary distribution of displacement: a) the whole model; b) section.

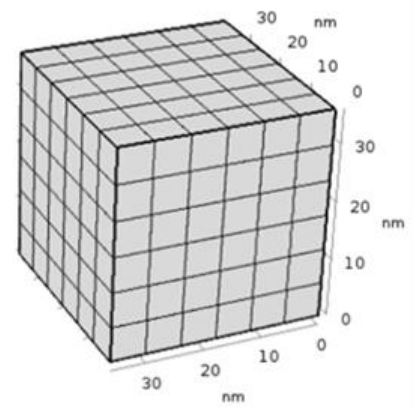

Fig. 7. A finite element model for homogenized material.

Table 5. Detailed information on finite elements for homogenized cube.

\begin{tabular}{|c|c|c|c|}
\hline $\begin{array}{c}\text { Mesh verti- } \\
\text { ces }\end{array}$ & $\begin{array}{c}\text { Hexahedral } \\
\text { elements }\end{array}$ & $\begin{array}{c}\text { Quadrilat- } \\
\text { eral ele- } \\
\text { ments }\end{array}$ & $\begin{array}{c}\text { Edge ele- } \\
\text { ments }\end{array}$ \\
\hline 343 & 216 & 216 & 72 \\
\hline $\begin{array}{c}\text { Vertex } \\
\text { elements }\end{array}$ & $\begin{array}{c}\text { Number of } \\
\text { elements }\end{array}$ & $\begin{array}{c}\text { Shape func- } \\
\text { tion }\end{array}$ & \\
\hline 8 & 216 & Quadratic & \\
\hline
\end{tabular}

To determine homogenized material properties defined as a design parameter, the limits to the design variables are applied as shown in table 6 .

The evolutionary algorithm was executed several times and the change of the value of the objective function for the subsequent generations for the best case on a logarithmic scale is shown in figure 8 . It is to minimize the difference between the RVE model and the homogeneous one, which is represented by formula (11). 
Table 6. Material parameters of M-R 9-parameters for matrix in micro model [MPa] (Gorash et al., 2015), EO - initial bulk modulus..

\begin{tabular}{|c|c|c|c|c|}
\hline $\mathrm{C} 10$ & $\mathrm{C} 01$ & $\mathrm{C} 20$ & $\mathrm{C} 02$ & $\mathrm{C} 11$ \\
\hline$[-0.5 ; 0.6]$ & {$[-0.2 ; 0.6]$} & {$\left[-5 \times 10^{-3} ; 6 \times 10^{-3}\right]$} & {$\left[-5 \times 10^{-4} ; 6 \times 10^{-4}\right]$} & {$\left[-5 \times 10^{-4} ; 6 \times 10^{-4}\right]$} \\
\hline $\mathrm{C} 30$ & $\mathrm{C} 03$ & $\mathrm{C} 21$ & $\mathrm{C} 12$ & $E_{0}, \mathrm{~Pa}$ \\
\hline$\left[-8 \times 10^{-5} ; 9 \times 10^{-5}\right]$ & {$\left[-5 \times 10^{-5} ; 6 \times 10^{-5}\right]$} & {$\left[-5 \times 10^{-5} ; 6 \times 10^{-5}\right]$} & {$\left[-5 \times 10^{-5} ; 6 \times 10^{-5}\right]$} & {$\left[3 \times 10^{6} ; 1.5 \times 10^{7}\right]$} \\
\hline
\end{tabular}

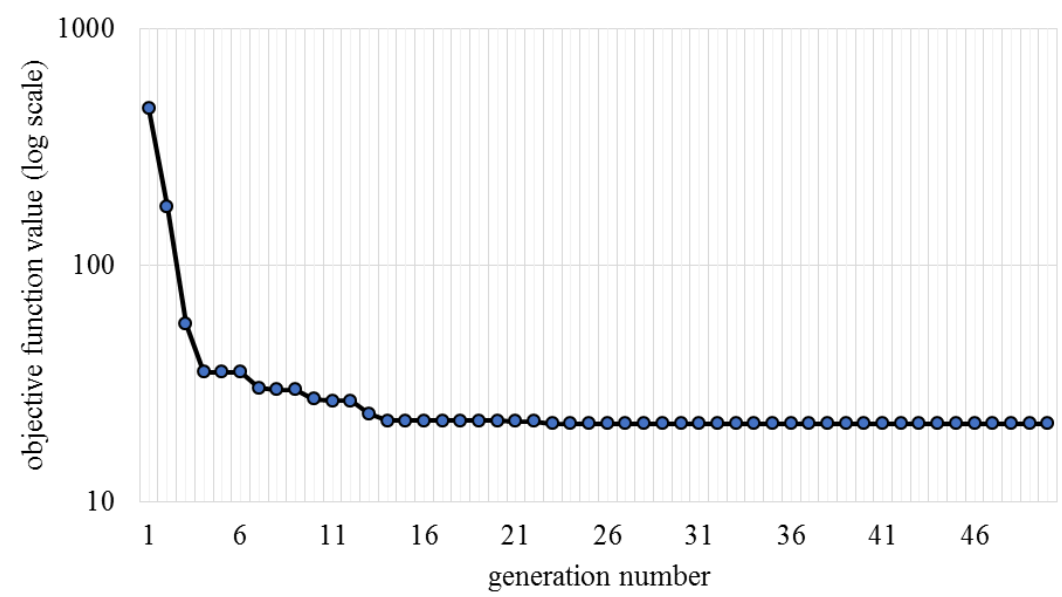

Fig. 8. Objective function value in each generation of evolutionary algorithm.

The objective function $f(x)$ for the best evolutionary algorithm solution is equal to 21.38 , while the material properties defined by genes are presented in table 7.

Table 7. The best-found values of material properties [MPa].

\begin{tabular}{|c|c|c|c|c|}
\hline $\mathrm{C} 10$ & $\mathrm{C} 01$ & $\mathrm{C} 20$ & $\mathrm{C} 02$ & $\mathrm{C} 11$ \\
\hline 0.192 & 0.0406 & $-1.87 \times 10^{-3}$ & $5.27 \times 10^{-4}$ & $-5.22 \times 10^{-6}$ \\
\hline $\mathrm{C} 30$ & $\mathrm{C} 03$ & $\mathrm{C} 21$ & $\mathrm{C} 12$ & $E_{0}, \mathrm{~Pa}$ \\
\hline $5.57 \times 10^{-5}$ & $1.74 \times 10^{-5}$ & $-4.86 \times 10^{-5}$ & $4.23 \times 10^{-5}$ & $5.30 \times 10^{6}$ \\
\hline
\end{tabular}

A distribution of displacements for one of the load cases, the extension in the " $z$ " direction for micro and homogenized model are shown in figure 9. The maximum displacement value for the case of stretching along the $Z$ axis was $35 \mathrm{~nm}$.

Graph of dependence of stress - strain depending on the case is shown in figures 10, 11 and 12. The curve for the detailed carbon black model coincides with the curve with substitute values of material constants.

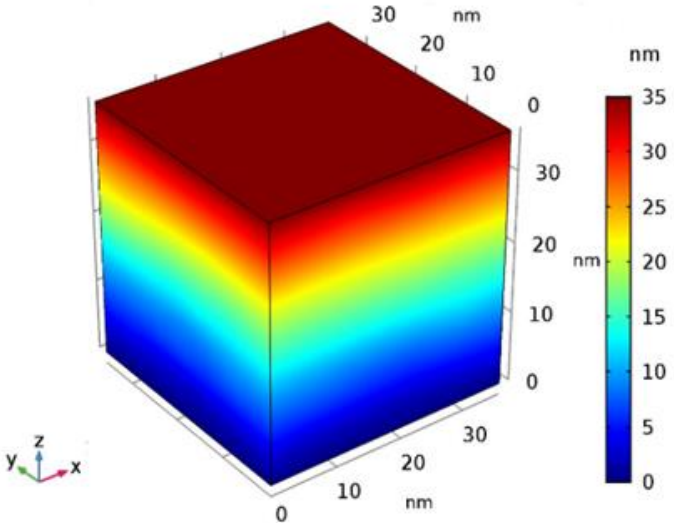

a)

Fig. 9. Distribution of displacement for homogenized model for extension in " $z$ " direction: a) the whole model; $b$ ) cross sections 


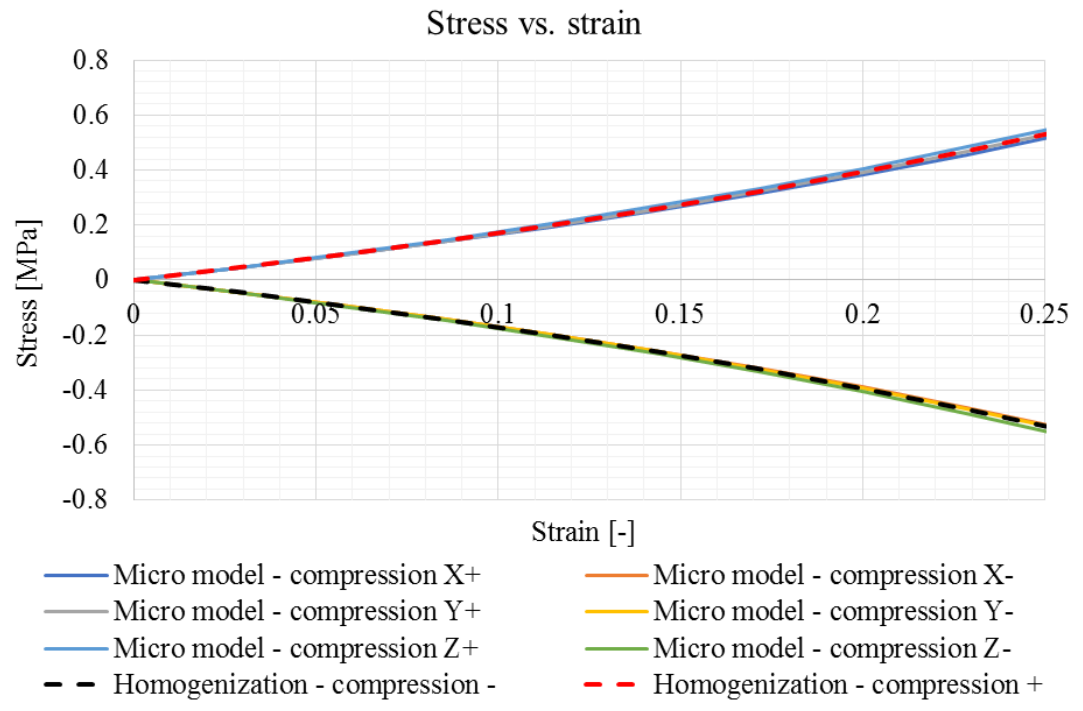

Fig. 10. Graph of dependence of the stress - strain for the stretching case.

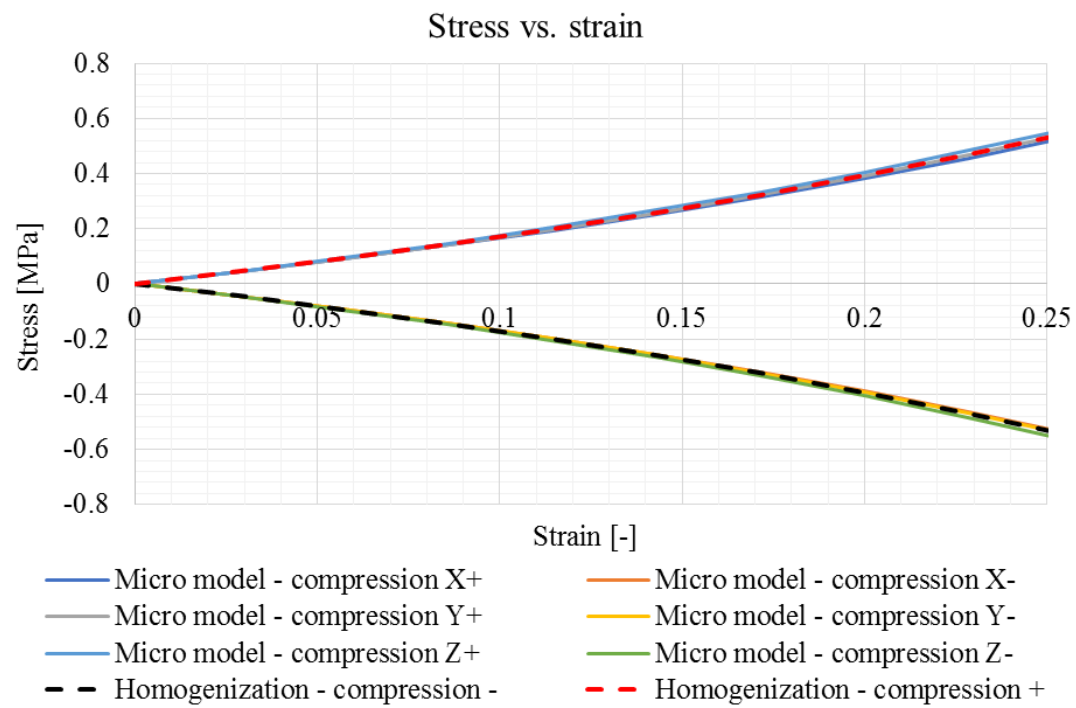

Fig. 11. Graph of dependence of the stress - strain for the compression case.

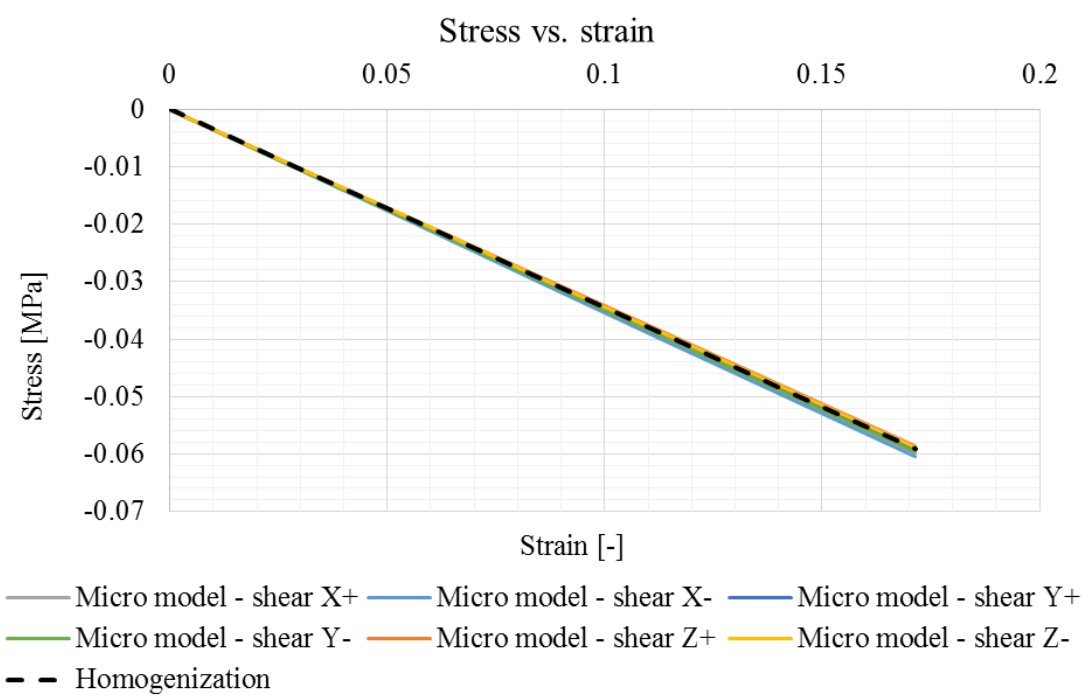

Fig. 12. Graph of dependence of the stress - strain for the shearing case. 
The influence of finite element mesh size on the quality of obtained results was checked for the model after homogenization. The article analyzes the homogenized model with 216 finite elements and it was compared to 2744 finite elements. The average relative errors (ARE) of reaction forces are shown in the table 8 .

Table 8. The average relative error depends on the number of finite elements.

\begin{tabular}{|c|c|c|c|}
\hline Average relative & Extension & Compression & Shear \\
\cline { 3 - 4 } error between the & & & \\
reaction forces of & & & \\
216 and 2744 & $0.028 \%$ & $0.192 \%$ & $0.118 \%$ \\
finite elements & & & \\
\hline
\end{tabular}

The homogenized material properties, were used to numerically calculate the trunk door seal when the car door was closed. The seal type D was assumed with the dimensions shown in Figure 13. The numerical calculations included a seal section with a length of $40 \mathrm{~mm}$. The properties of the finite element mesh are shown in table 9.

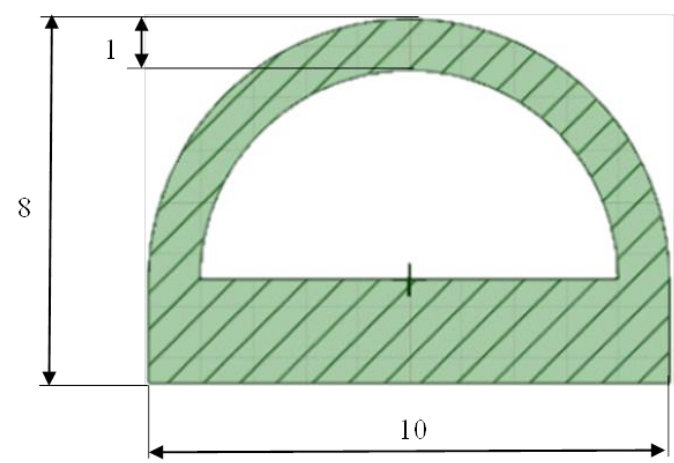

Fig. 13. Geometry of trunk door seal.

Table 9. Detailed information on finite elements.

\begin{tabular}{|c|c|c|c|}
\hline $\begin{array}{c}\text { Mesh } \\
\text { vertices }\end{array}$ & $\begin{array}{c}\text { Hexahedral } \\
\text { elements }\end{array}$ & $\begin{array}{c}\text { Quadrilateral } \\
\text { elements }\end{array}$ & $\begin{array}{c}\text { Edge } \\
\text { elements }\end{array}$ \\
\hline 32118 & 25000 & 14700 & 1084 \\
\hline $\begin{array}{c}\text { Vertex } \\
\text { elements }\end{array}$ & $\begin{array}{c}\text { Number of } \\
\text { elements }\end{array}$ & $\begin{array}{c}\text { Shape func- } \\
\text { tion }\end{array}$ & \\
\hline 16 & 25000 & Quadratic & \\
\hline
\end{tabular}

The FEM model of the trunk door seal model is shown in figure 14. The boundary conditions of the numerical model are shown in figure 15.

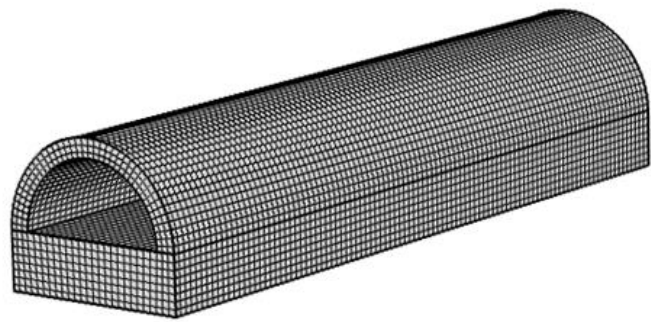

Fig. 14. The FEM model of the trunk door seal

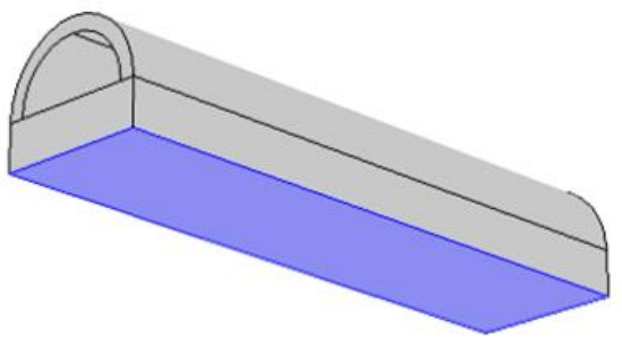

a)

b)

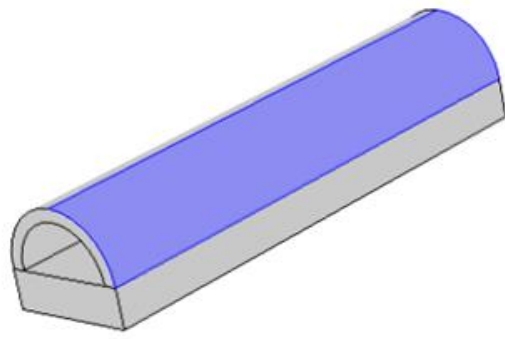

Fig. 15. The boundary condition: a) all DOFs fixed; b) the force.

The Mises stress distribution and total displacement are shown in Figure 16 and 17 respectively.

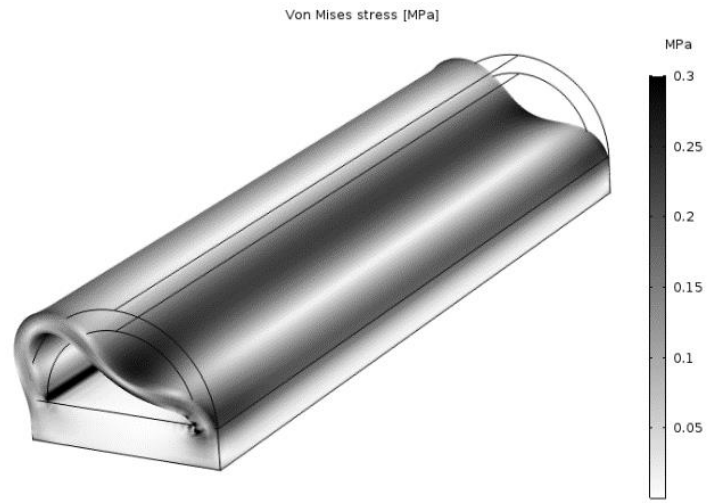

b)

Fig. 16. The distribution of von Mises stress, MPa. 


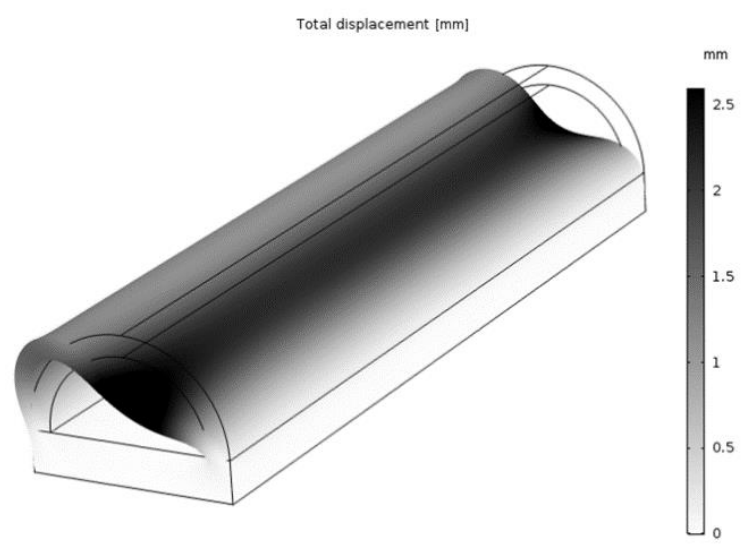

b)

Fig. 17. The distribution of total displacement, $\mathrm{mm}$.

\section{DISCUSSION}

The decoupled homogenization method applied to the analysis of the trunk door seal allows analysis to be done taking into account very small (compared to the macro model size) inclusions. The numerical material tests in micro scale are the part of the algorithm that in many cases consumes the most of the computing. The evolutionary algorithm used in homogenization procedure allows one to obtain solution of multimodal optimization problem. The presented decoupled method can be used in many applications of hyperelastic materials and the numerical example described confirmed the possibility to perform computation in macro scale that takes into account nanoscale size of inclusions, without the need of preparing material samples and performing experimental tests. It is convenient if the composite is in a design phase and the material is not yet allowable for experimental testing.

\section{REFERENCES}

Burczyński, T., Kuś, W., Beluch, W., Długosz, A., Poteralski, A., Szczepanik M., 2020, Intelligent computing in optimal design, Springer-Nature.

Fish, J, 2013, Practical multiscaling, Wiley.

Fung, Y.C., 1993, Biomechanics, Mechanical properties of living tissues, Springer, 300-314.

Gorash, Y., Comlekci, T., Hamilton, R., 2015, CAE-based application for identification and verification of hyperelastic parameters, Department of Mechanical \& Aerospace Engineering, University of Strathclyde, Glasgow.

Industrial rubber carbon blacks, Continental Carbon: http: //www.continentalcarbon.com/industrial-rubber-carbonblack.asp (accessed on 09.10.2019).

Kyungwhan, Y., Kyoungah, C., Sangsig, K., 2018, Effect of carbon black addition on thermal stability and capacitive performances of supercapacitors. Scientific Reports, volume 8, Article number: 11989.

López Jiménez, F., Pellegrino, S., 2012, Constitutive modeling of fiber composites with a soft hyperelastic matrix, Inter- national Journal of Solids and Structures, 49(3-4), 635647.

Madej, Ł., Mrozek, A., Kuś, W., Burczyński, T., Pietrzyk, M., 2008, Concurrent and upscaling methods in multi scale modelling - case studies, Computer Methods in Materials Science, 8(1), 1-15.

Michalewicz, Z., 1996, Genetic algorithms + data structures = evolutionary algorithms, Springer-Verlag, Berlin.

Nonlinear multi-scale modeling of rubber and tires with DIGIMAT, e-Xtream Engineering: https://magicengineering.ro/uploads/2017/05/Nonlinear-Multi-scaleModeling-of-Rubber-and-Tires-with-Digimat.pdf (accessed on 09.10.2019).

Prevost, T.P., Balakrishnan, A., Suresh, S., Socrate, S., 2011, Biomechanics of brain tissue, Acta Biomaterialia, 7, 8395.

Rackl, M., 2015, Curve fitting for ogden, yeoh and polynomial models. ScilabTech Conference, Paris, I(1),1-11.

Rauch, L., Szeliga, D., Bachniak, D., 2015, Identification of multi-inclusion statistically similar representative volume element for advanced high strength steels by using data farming approach. Procedia Computer Science, 51(1), 924-933.

Terada, K., Kato, J., Hirayama, N., Inugai, T., Yamamoto, K., 2013, A method of two-scale analysis with micro-macro decoupling scheme: application to hyperelastic composite materials, Computational Mechanics, 52, 1199-1219.

Thompson, B., 2010, Thermax N990 medium thermal carbon black in nitrile rubber compounds, Cancarb.

Ungar, T., Gubicza, J., Ribarik, G., Pantea, C., Zerda, T.W., 2002, Microstructure of carbon blacks determined by Xray diffraction profile analysis, Carbon, 40(6), 929-937.

Xu, L., Yong, X., Ziran, L., Yuanming, X., 2012, Threedimensional numerical simulations on the hyperelastic behavior of carbon-black particle filled rubbers under moderate finite deformation, Computational Materials Science, $55,157-165$.

\section{NIESPRZEŻ̇ONA HOMOGENIZACJA KOMPOZYTU HIPERSPRĘŻYSTEGO Z WTRACENIAMI SADZY}

\section{Streszczenie}

Celem pracy było zastosowanie metody homogenizacji niesprzężonej do modelowania hipersprężystego kompozytu $\mathrm{Z}$ wtrąceniami. Metodę przedstawioną w pracy ilustruje analiza numeryczna uszczelki drzwi. Metodę homogenizacji niesprzężonej zastosowano w celu określenia makroskopowych właściwości materiału hipersprężystego. Metoda pozwala wyznaczyć równoważne właściwości materiału kompozytowego na podstawie jego struktury i wyników eksperymentów numerycznych prowadzonych w skali mikro. W przeciwieństwie do metody sprzężonej wyniki nie są przenoszone w każdej iteracji między skalami, co prowadzi do obniżenia kosztów obliczeń. Analizowany mikro model składał się z osnowy z materiału hipersprężystego oraz sztywnych wtrąceń sadzy. Metoda niesprzężona wykorzystuje algorytm ewolucyjny, aby uzyskać właściwości materiału makro. Do analiz numerycznych użyto metody elementów skończonych.

Received: April 14, 2020 Received in a revised form: May 7, 2020 Accepted: May 12, 2020. 